\title{
Observations of High Densities and Rates of Positive Flashes in Summertime Thunderstorms in Brazil
}

\author{
Rosangela B.B. Gin \\ Osmar Pinto Jr. \\ Iara R.C.A. Pinto \\ Odim Mendes Jr
}

Instituto Nacional de Pesquisas Espaciais - INPE/DGE

\begin{abstract}
Observations of summertime thunderstorms in Brazil in 1993 indicate periods with the predominance of positive cloud-to-ground lightning flashes. The periods present high density (average value of $0.66 / \mathrm{km}^{2} \mathrm{~h}$.) and high hourly rate (average value of $478 / \mathrm{h}$ ) of positive flashes. In most cases, they occurred at or near the beginning of the storm's cloud-to-ground lightning activity and had duration of about $2.5 \mathrm{~h}$.
\end{abstract}

\section{INTRODUCTION}

The first evidence of thunderstorm with predominance of positive cloud-to-ground lightning flashes in Brazil, called positive storms, were obtained by simultaneous balloon and lightning ground system measurements in 1989 (Gin, 1992; Pinto et al., 1992). Afterwards, Gin et al. (1996), Gin (1997) and Pinto Jr. et al. (1997) have confirmed such an evidence analysing data obtained by the Lightning Positioning and Tracking System (LPATS) during the summer season of 1993 in the state of Minas Gerais.

In this paper it will be analysed the data obtained during 12 positive storms which occurred in the summer season of 1993 in terms of flash density and hourly rate. The synotic meteorological conditions associated with the storms were identified (in most cases) through images of the Meteosat-3 satellite. The results are compared with similar observations made by Stolzenburg (1994) in the Great Plains of the United States.

\section{OBSERVATIONS AND DISCUSSION}

About 300,000 cloud-to-ground lightning flashes were measured by the LPATS during the summer season of 1993 in the state of Minas Gerais, in the southeastern region of Brazil. The main characteristics associated with the positive flashes (about 35\%) were the low peakcurrent intensity (average of $21 \mathrm{kA}$ ) and the occurrence of 20 periods in which they were predominant (average of $64 \%$ during these periods). The average duration of these periods was 4 hours (Pinto et al., 1997). During these periods the positive flashes occurred at almost same region of the negative flashes, not showing any evidence of a bipolar pattern. A bipolar pattern in the thunderstorm lightning activity has observed by serveral authors (e.g. Orville et al., 1988).

12 out of 20 positive storms shown high density and high hourly rate of positive flashes. Table 1 summarizes the main characteristics of positive flashes during these storms. The average density $\left(0.66 / \mathrm{km}^{2} \mathrm{~h}\right)$ and hourly rate $(478 / \mathrm{h})$ were higher than the values obtained by Stolzenburg (1994) in the Great Plains of the United States, $0.18 / \mathrm{km}^{2} \mathrm{~h}$ and $114 / \mathrm{h}$, respectively. Most storms were located at latitudes of $18-20^{\circ} \mathrm{S}$ and longitudes of 44$48^{\circ} \mathrm{W}$, and were associated with the presence of a cold front (SF). The periods of high density of positive flashes have average duration of 2.5 hours, and occurred at (6 cases) or near ( 6 cases) the beginning of the storm's cloud-to-ground lightning activity. During these periods, the storms presented a high percentage of positive flashes (average of $70 \%$ ). The positive flashes have an average peak current of $18 \mathrm{kA}$. These values is much lower than the average value of $70 \mathrm{kA}$ found by Stolzenburg for similar periods.

The maximum values of density and hourly rate of positive flashes were observed in March 11, 1993. These values, $2.53 / \mathrm{km}^{2} \mathrm{~h}$ and $1576 / \mathrm{h}$, respectively, are about 4 times greater than the maximum values obtained by Stolzenburg (1994) of $393 / \mathrm{h}$ and $0.6 / \mathrm{km}^{2} \mathrm{~h}$. Figure 1 shows the location of positive and negative lightning flashes during the storm of March 11, 1993. About 2500 positive flashes occurred during a 2 hour period, with an average hourly percentage of $83 \%$.

The duration of the period of high density of positive flashes showed variations from 1 to 5 hours. Figure 2 shows the duration of the high density period of positive flashes versus the number of positive flashes. Differently from Stolzenburg (1994), who found a weak correlation between these parameters, no correlation was found in this study. This fact seems to be a direct consequence of the large variation in the positive flash density (see Table 1).

\section{CONCLUSIONS}

As it has been identified by Stolzenburg (1994) in the Great Plains of the United States, the positive storms in Brazil also show high flash density and hourly rate. The values, however, are about 4 storms higher than found by Stolzenburg (1994). The number of positive flashes in a given storm is not correlated with the duration of the storm, reflecting the large variations in the positive flash density. The average peak-current intensity of the positive flashes was found to be $18 \mathrm{kA}$.

These value is much lower than the average value of 70kA found by Stolzenburg (1944). 
Athough there are similarities between the positive storms presented in the paper and those reported by Stolzenburg (1994), some differences were found. In this sense, the suggestion given by Stolzenburg (1994) that the positive storms may be related to tall storms that exhibit a stage of early, rapid increase in radar echo-top height and produce large hail may not be valid in this sense. More research is necessary in order to identify which mechanism or mechanisms are responsible for such storms.

(a) Strokes Received/Loaded

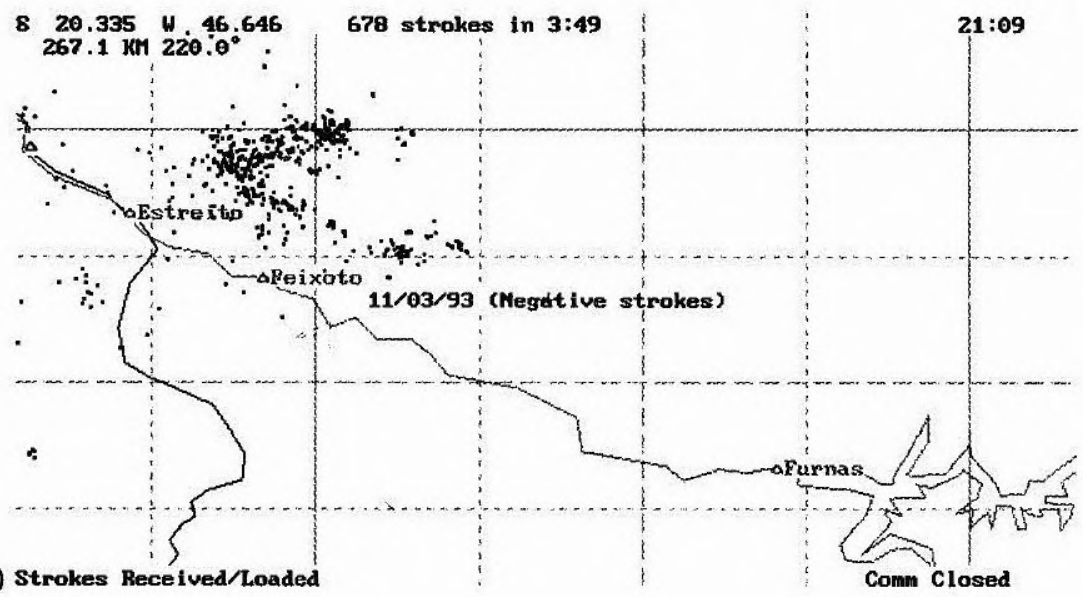

(b) Strokes Received/Loaded

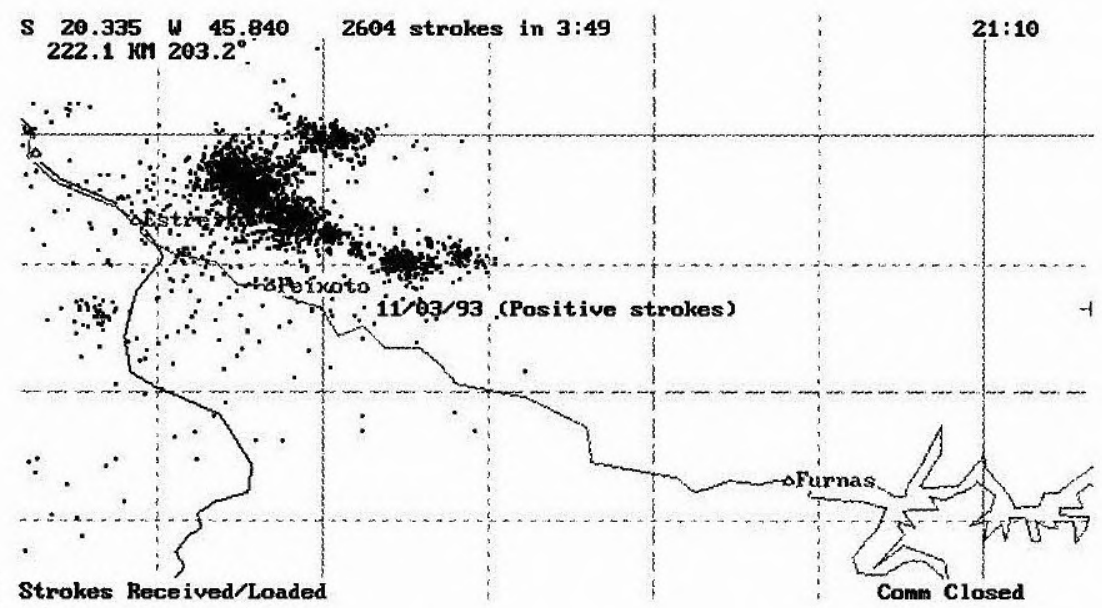

Fig. 1 - The location of negative (a) and positive (b) cloud-to-ground lightning flashes during the storm of March 11, 1993.

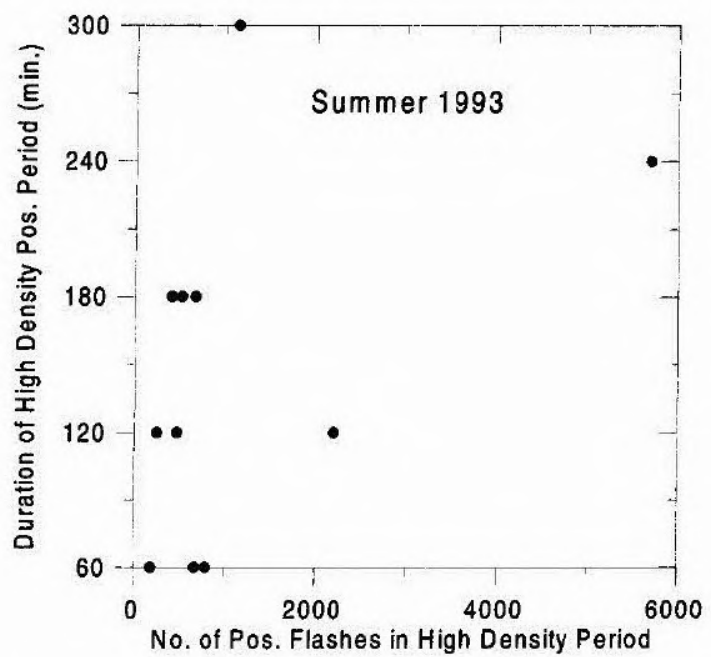

Fig. 2 - Total number of positive flashes related to the duration (min) of high density lightning period for 12 storms in Table 1. 
Table 1. Characteristics of positive CG lightning flashes in summertime thunderstorms in Brazil

\begin{tabular}{|c|c|c|c|c|c|c|c|}
\hline $\begin{array}{c}\text { Date } 1993 \\
\text { (Pos.-Storm } \\
\text { period -UT) }\end{array}$ & $\begin{array}{l}\text { Location } \\
\text { Lat.: }{ }^{\circ} \mathrm{S} \\
\text { Long: }{ }^{\circ} \mathrm{W}\end{array}$ & $\begin{array}{c}\text { High-pos. } \\
\text { time-period } \\
\text { (UT) } \\
\text {. }\end{array}$ & $\begin{array}{c}\text { Average } \\
\text { hourly } \\
\text { percent } \\
\text { pos. } \\
\end{array}$ & $\begin{array}{c}\text { Total } \\
\text { number } \\
\text { of pos } \\
\text { flashes }\end{array}$ & $\begin{array}{c}\text { Max. pos. } \\
\text { rate }(/ h)\end{array}$ & $\begin{array}{l}\text { Max. pos. } \\
\text { density } \\
\left(\mathrm{km}^{2} / \mathrm{h}\right)\end{array}$ & $\begin{array}{l}\text { Meteorolog. } \\
\text { Condition }\end{array}$ \\
\hline $\begin{array}{l}\mathbf{1 1 / 0 1 - 1 2 / 0 1} \\
(2200-0300)\end{array}$ & $\begin{array}{l}18-20 \\
43-45 \\
\end{array}$ & $2200-0300$ & 62 & 1135 & 459 & 0.13 & Assoc. SF \\
\hline $\begin{array}{c}16 / 01 \\
(1400-1700)\end{array}$ & $\begin{array}{l}20-21 \\
43-44 \\
\end{array}$ & $1500-1700$ & 82 & 479 & 258 & 0.65 & Isolate \\
\hline $\begin{array}{c}17 / 01 \\
(0700-1000)\end{array}$ & $\begin{array}{l}19-20 \\
43-44 \\
\end{array}$ & $0700-1000$ & 84 & 416 & 302 & 0.38 & Assoc. SF \\
\hline $\begin{array}{l}\mathbf{1 1 / 0 2 - 1 2 / 0 2} \\
(0000-0200\end{array}$ & $\begin{array}{l}21-22 \\
44-45 \\
\end{array}$ & $0000-0200$ & 60 & 262 & 147 & 0.05 & $*_{--}$ \\
\hline $\begin{array}{l}\mathbf{1 3 / 0 2 - 1 4 / 0 2} \\
(2300-0200)\end{array}$ & $\begin{array}{l}19-20 \\
47-49 \\
\end{array}$ & $2300-0200$ & 51 & 527 & 272 & 0.46 & $*_{-}$ \\
\hline $\begin{array}{c}\mathbf{2 0 / 0 2} \\
(0100-0500)\end{array}$ & $\begin{array}{l}18-20 \\
47-49\end{array}$ & 0200-0500 & 67 & 676 & 306 & 0.06 & $*_{--}$ \\
\hline$(1200-1500)$ & $\begin{array}{l}20-21 \\
46-47 \\
\end{array}$ & $1200-1500$ & 75 & 422 & 292 & 0.19 & *-- \\
\hline $\begin{array}{c}\mathbf{2 2 / 0 2} \\
(0000-0300)\end{array}$ & $\begin{array}{l}20-21 \\
43-44\end{array}$ & 0200-0300 & 60 & 800 & 800 & 0.8 & $*_{--}$ \\
\hline $\begin{array}{l}\mathbf{2 2 / 0 2 - 2 3 / 0 2} \\
(2300-0200)\end{array}$ & $\begin{array}{r}17-19 \\
47-48 \\
\end{array}$ & $0000-0100$ & 52 & 199 & 199 & 0.22 & $*_{--}$ \\
\hline $\begin{array}{c}\mathbf{1 1} / \mathbf{0 3} \\
(1400-1800)\end{array}$ & $\begin{array}{l}20-21 \\
46-48 \\
\end{array}$ & $1600-1800$ & 83 & 2209 & 1576 & 2.53 & Assoc. SF \\
\hline $\begin{array}{c}12 / 03 \\
(1300-1600)\end{array}$ & $\begin{array}{r}19-20 \\
47-48 \\
\end{array}$ & $1500-1600$ & 85 & 679 & 679 & 0.85 & Assoc. SF \\
\hline $\begin{array}{c}\mathbf{1 3} / \mathbf{0 3} \\
(1500-1900)\end{array}$ & $\begin{array}{l}19-20 \\
45-47 \\
\end{array}$ & $1500-1900$ & 77 & 5700 & 675 & 2.25 & Assoc. SF \\
\hline Average & & $2.5 \mathrm{~h}$ & 70 & 1038 & 478 & 0.66 & \\
\hline
\end{tabular}

*No meteorological satellite data available.

\section{ACKNOWLEDGMENTS:}

The authors would like to thank the Companhia Energética de Minas Gerais (CEMIG) for providing the lightning data and the Fundação de Amparo à Pesquisa do Estado de São Paulo (FAPESP) and the CNPq for supporting during the research.

\section{REFERENCES}

GIN, R.B.B. Estudo das Características de Relâmpagos no Sudeste do Brasil no Verão de 1992-93. PhD Thesis, Instituto Nacional de Pesquisas Espaciais, São José dos Campos, Brazil, In Press, 1997.
GIN, R.B.B. Estudo coordenado de um sistema de tempestade sobre a América do Sul. Ms thesis, Instituto Nacional de Pesquisas Espaciais, São José dos Campos, Brazil, 1992. (INPE - 5388 - TDI / 477).

GIN, R.B.B; PINTO JR., O.; PINTO, I.R.C.A.; MENDES JR., O. Tempestades Positivas no Sudeste do Brasil. Anais da IX Congresso Brasileiro de Meteorologia SBMET, São Paulo, Nov.1996, p.15.

ORVILLE, R.E.; HENDERSON, R.W.; BOSART, L.F. Bipole patterns revealed by lightning locations in mesoscale storm systems. Geophysical Research Letters, 15(2):129-132, Feb. 1988.

PINTO, I.R.C.A.; PINTO JR., O.; GIN, R.B.B.; DINIZ, J.H.; ARAUUJO, R.L.; CARVALHO, A.M. A coordinated study of a storm system over the south american continent 
2. lightning-related data. Journal of Geophysical Research, 97 (D16) : 18205-18213, 1992.

PINTO JR., O.; GIN, R.B.B.; PINTO, I.R.C.A.;

MENDES JR., O. Cloud-to-ground lightning characteristics in the Southeastern Brazil during the 199293 summer season. Journal of Geophysical Research, 101 (D23): 29627-29635, 1996.

PINTO JR., O.; PINTO, I.R.C.A; GIN, R.B.B.; MENDES

JR., O.. Positive thunderstorms in Brazil. Annales Geophysicae, in press, 1997.

STOLZENBURG, M. Observations of high ground flash densities of positive lightning in summertime thunderstorms. Monthly Weather Review, $\underline{122}$ : 17401749, Aug. 1994. 